ノート・ Note

\title{
水熱条件下におけるシリカの固化
}

\author{
山崎仲道・西岡 守・柳沢和道・叶原悟司
}

(高知大学 理学部附属水熱化学実験所)

(1983 年 7 月 25 日受付)

\section{Aggregate Formation of Silica under Hydrothermal Conditions}

\author{
Nakamichi YAMASAKI, Mamoru NISHIOKA, Kazumichi YANAGISAWA and \\ Satoshi KANAHARA \\ Research Laboratory of Hydrothermal Chemistry, Faculty of Science, \\ Kochi University \\ 2-5-1, Akebono-cho, Kochi-shi 780
}

[Received July 25, 1983]

\begin{abstract}
Key-words : Hydrothermal hot-pressing, Apparatus for measurement of shrinkages, Lithification, Quartz grain
\end{abstract}

\section{1. 緒言}

水熱人造岩石中に高レベル廃棄物を封じ込む研究で, ケイ石粉末と白土の混合物に水酸化ナトリウム水溶液を 加え水熱条件下でホットプレスを行い，得られた硬化体 は高い圧縮強度を示す。これについては，先の日本原子 力学会誌で報告した1!. しかし, 水熱条件下での硬化過 程は明らかにされていない。

また，種々のケイ酸カルシウムに関する研究21-4) にお いても，反応後の試料について測定を行うことが普通で 反応中の硬化過程についての資料は少ない. 硬化過程は, 硬化反応中の収縮率の測定によってその概略を知ること ができる。しかし，その測定資料はほとんどなく，むし ろホットプレスによる焼結中の資料が多( ${ }^{5)-71}$.

水熱条件下のホットプレスについては，松岡らが続成 作用の実験的研究 ${ }^{81}$ として無機微粉末の水熱ホットプレ スを行い，硬化体の収縮率を測定したが硬化反応中の収 縮については測定していない.

そこで著者らは，反応中の試料の収縮量を直接測定で きる装置を設計・作製し，ケイ石・白土の混合物の水熱 反応中の硬化過程を検討した。

\section{2. 実験}

本実験では，福島県産ケイ石と鹿児島県産白土を用い た。ケイ石は $99 \% \alpha$-石英, 白土は無定形シリカであった。 ケイ石のみ 300 メッシュ以下の粒度に調整し, ケイ石・ 白土の配合比を $7: 3,1: 1,3: 7$ としてボールミルで 5 時間混合した。

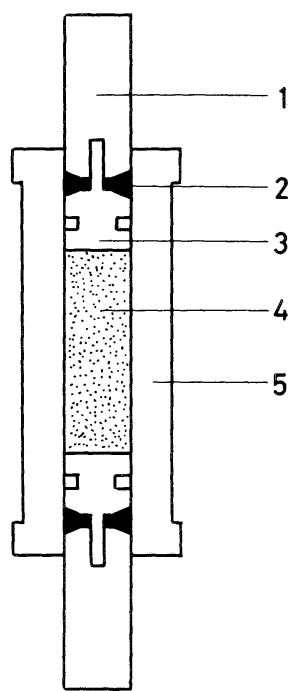

Fig. 1. Hot-pressing autoclave. 1 : Push rod of piston, 2: Gland packing, $3:$ Piston, $4:$ Sample, $5:$ Cylinder

ホットプレス用オートクレーブを図 1 に示す。試料を 直接押し棒によって圧縮でき，押し棒には硬化体からの 水の逃げの空間を設けてある。また，加熱はシース型フ レキシブルヒーターをオートクレーブ外壁に直接巻きつ けて行った。収縮量測定装置の原理図を図 2 に示す。ワ イヤーの先に取り付けた荷重(1)が滑車(2)を経てVベル

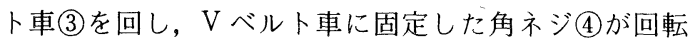
する.そして，架台との間にピン(5)を入れることにより， 


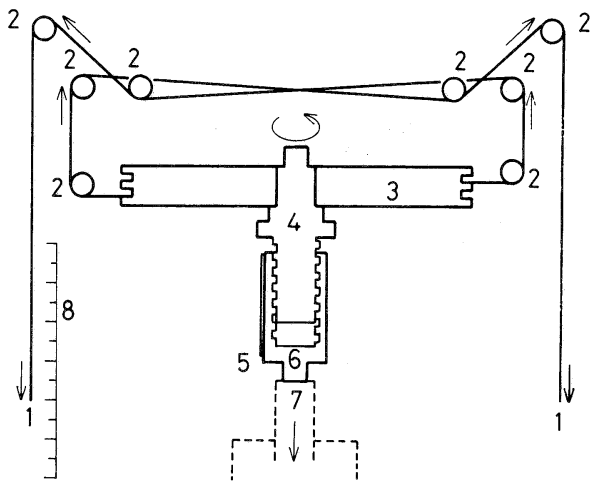

Fig. 2. Apparatus for measurement of shrinkages during the hydrothermal hot-pressing.

1: Load, 2 : Pulley, $3:$ V-belt wheel, $4:$ Square thread, $5:$ Pin, $6:$ Square thread nut, $7:$ Push rod, $8:$ Scale

Vベルト車の回転を角ネジナット6が下部方向の動き に換え，オートクレーブ押し棒(7)に一定圧が加わるよう になっている，また，反応中の収縮量はワイヤーの伸び によって直接測定できる. ワイヤーのスケール8は，押 し棒の進入する長さの約 130 倍であり感度が高い，

ケイ石・白土の混合物 $20 \mathrm{~g}$ と水酸化ナトリウム水溶 液 $6 \mathrm{~N} 4.4 \mathrm{ml}$ を乳鉢で練り, 予備圧 $400 \mathrm{~kg} / \mathrm{cm}^{2}$ で 60 秒間加圧後, $120 \mathrm{~kg} / \mathrm{cm}^{2}$ で圧縮圧力を保ちながら $28^{\circ} \mathrm{C} / \mathrm{min}$ で昇温を行い，昇温中の試料の収縮経過を測 定した. 所定温度に達してから, 15 分間温度を保持した。 得られた硬化体は, $100^{\circ} \mathrm{C}$ の水で 30 分間洗浄し, 乾燥後, 顕微鏡観察・圧縮強度を測定した。

硬化反応中の収縮率は, 次式によって求めた。

収縮率 $(\%)=100 \cdot \Delta l /(\Delta l+l)$

ここで $\Delta l:$ 押し棒が進入した距離

$l:$ 反応終了後の硬化体の長さ

\section{3. 結果と考察}

昇温中における各配合比試料の収縮率変化の一例を図 3 に示す。各配合比の $250^{\circ} \mathrm{C}$ での収縮は, 保持時間中 に生じたものである. 配合比の変化による全収縮率の差 は，2３\% と大きくなかった。硬化反応中の収縮は $100^{\circ} \mathrm{C}$ 以下では見られず，ケイ石・白土 $1: 1$ と $3: 7$ は $105^{\circ} \mathrm{C}, 7: 3$ は $120^{\circ} \mathrm{C}$ で最初の収縮が生じた。昇温中 の収縮は, 図に示すように連続的ではなく不連続に数回 生じた。例えば，ケイ石・白土 $7: 3$ は， $120^{\circ} \mathrm{C}$ で $2 \%$, $140^{\circ} \mathrm{C}$ で $6 \%, 150^{\circ} \mathrm{C}$ で $10 \%, 195^{\circ} \mathrm{C}$ で $14 \%, 250^{\circ} \mathrm{C}$ で $17 \%$ となった。これらの収縮は, 全収縮率の半分以上 を占める $100^{\circ} \sim 150^{\circ} \mathrm{C}$ での収縮, 次に $180^{\circ} \sim 200^{\circ} \mathrm{C}$, $230^{\circ} \sim 250^{\circ} \mathrm{C}$ と大きく 3 段階に分かれていることが分っ た。

これらの収縮過程を考察するために各段階での硬化体

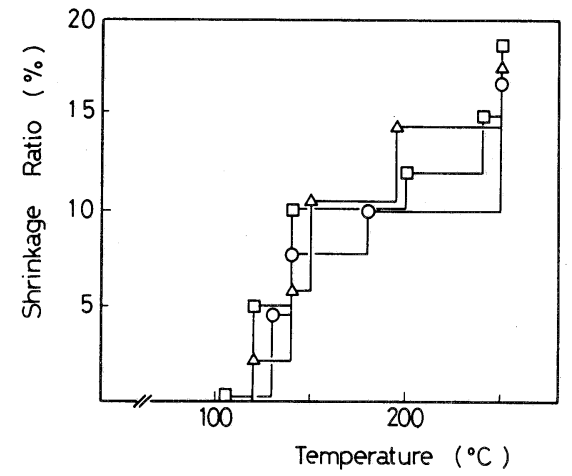

Fig. 3. Relation between shrinkage ratio and temperature during the hydrothermal hot-pressing. $\triangle:$ Silica stone/siliceous sinter $=7 / 3$, : Silica stone/siliceous sinter $=1 / 1$, $\square$ : Silica stone/siliceous sinter $=3 / 7$

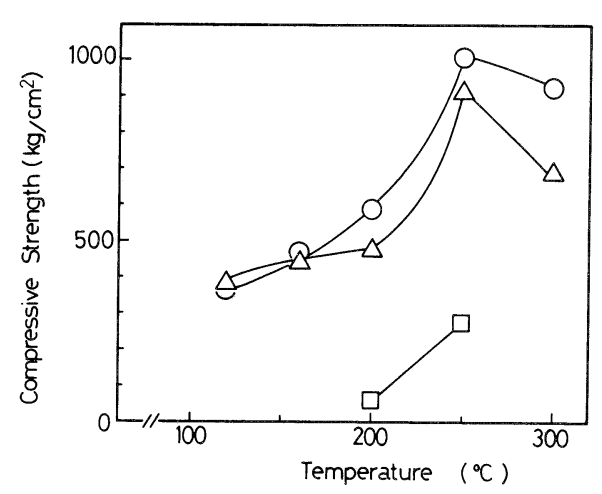

Fig. 4. Compressive strength of the hydrothermally hardened bodies.

$\triangle:$ Silica stone/siliceous sinter $=7 / 3$,

$\bigcirc$ : Silica stone/siliceous sinter $=1 / 1$,

$\square$ : Silica stone/siliceous sinter $=3 / 7$

をそれぞれ作製し，硬化体の圧縮強度測定・金属顕微鏡 観察を行った.

各試料の圧縮強度と温度の関係を図 4 に示す，圧縮強 度は, 第 2 段階の収縮後の $200^{\circ} \mathrm{C}$ までは徐々に増加す るが第 3 段階の収縮後の $250^{\circ} \mathrm{C}$ では急激に増加し最高 強度を示した。このことから $200^{\circ} \mathrm{C}$ までは収縮率は大 きいが，これらの収縮が硬化体の圧縮強度に与える髪響 は少ない。したがって, $200^{\circ} \mathrm{C}$ までの収縮と $200^{\circ} \mathrm{C}$ 以 上での収縮は異なった硬化過程によるものであると考え られる。

処理温度 $300^{\circ} \mathrm{C}$ で圧縮強度が減少している理由は, 硬化反応が溶解・析出型によると考えれば, 溶解が進み 過ぎて析出を起こさないためと考えられる.

硬化体の顕微鏡写真を図 5 に示す。高温ほど石英粒子 の成長が見られる.これは, 大粒が小粒を食うことによ ると考えられ，この硬化反応が溶解・析出型であること を裏付けている. $250^{\circ} \mathrm{C}$ では, 石英粒子間の結合が観察 

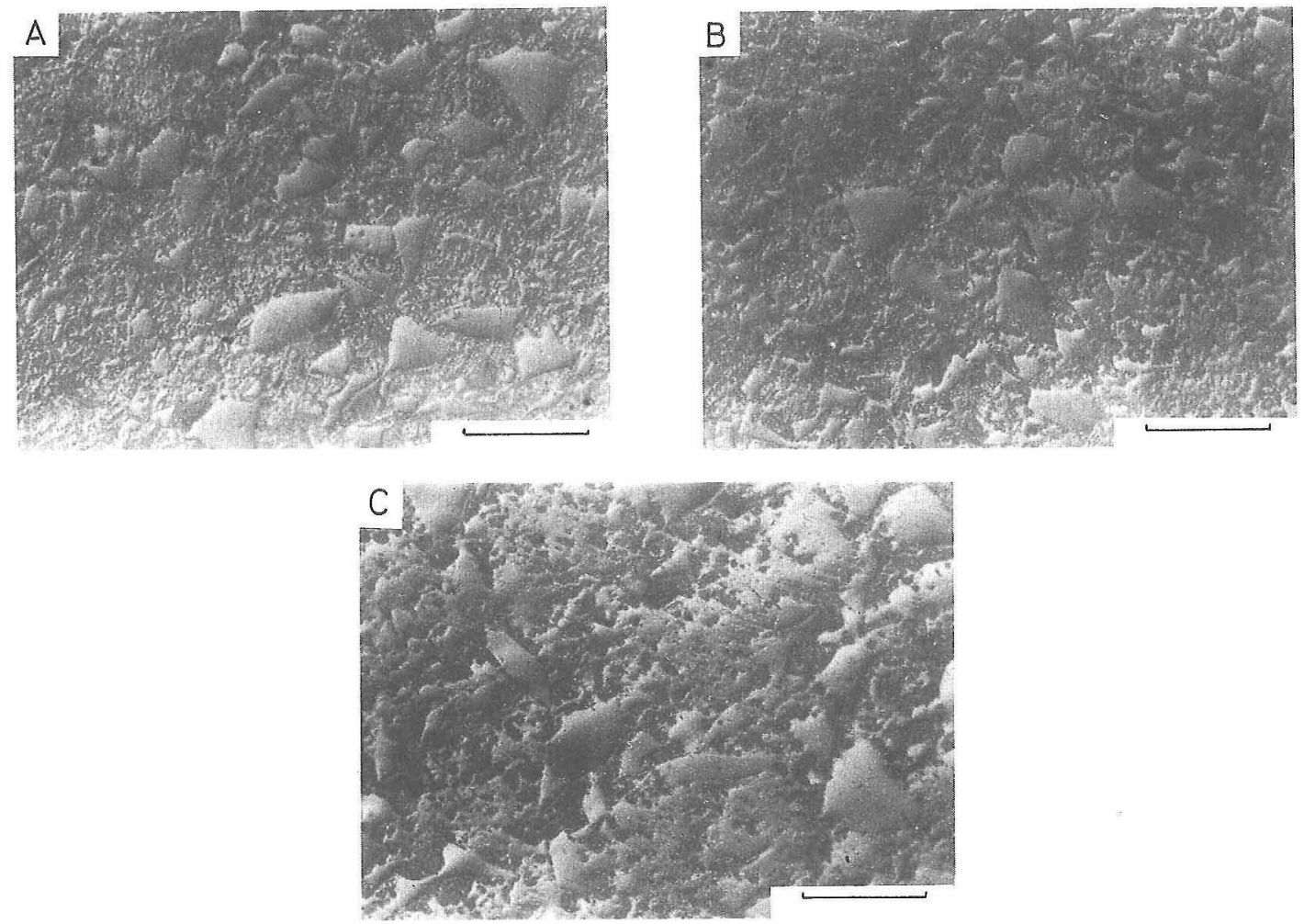

Fig. 5. Microstructure of the hardened bodies. Silica stone/siliceous sinter $=1 / 1$ (A) $160^{\circ} \mathrm{C}$, (B) $200^{\circ} \mathrm{C}$, (C) $250^{\circ} \mathrm{C}, \mathrm{Bar}=20 \mu \mathrm{m}$

され，最大強度がこの石英粒子間の結合によることが推 察される。

これらのことから，全収縮率の半分以上の収縮が生じ る $100^{\circ} \sim 150^{\circ} \mathrm{C}$ では石英粒子にはほとんど影響なく，白 土の溶解・結合による収縮が主であり， $180^{\circ} \sim 200^{\circ} \mathrm{C}$ で の収縮は白土による石英粒子間の結合による収縮， $230^{\circ}$ $\sim 250^{\circ} \mathrm{C}$ での収縮は，石英粒子のからみ合いによる収縮 であると思われる。

\section{文献}

1) 山崎仲道, 柳沢和道, 西岡 守, 叶原悟司, 日本原子学 会誌比投稿中。

2) T. Mitsuda, Miner. Journ, , 6, 147-58 (1970).

3）鈴木一孝, 浦川忠彦, 伊藤祐敏, 䁇協, 82, 574-82(1974).

4）久保和彦,御屁秀俊, 山口悟郎, 窒協, 83, 599-603(1975).

5) A. Tsuge, H. Inoue and K. Komeya, Yogyo-Kyokai-Shi, 82, 587-96 (1974).

6）長谷貞三，鈴木弘茂，璂協，88，161-68（1980）.

7) E. I. Neproshin, T.A. Ostrouskaya et al., Sov. Pore der Met. Metal. Ceram., 13, 210-12 (1974).

8）松岡 清他，水熱化学実験所報告，3，8-11 (1979) 